\title{
Does Market Size Matter for How Trade Openess Affects Economic Growth?
}

\author{
Farrokh Kahnamoui $^{1,2}$ \\ ${ }^{1}$ Department of Economics, Western Washington University, Bellingham WA, USA \\ ${ }^{2}$ Department of Economics, Southern Illinois University, Carbondale, IL, USA \\ Correspondence: Farrokh Kahnamoui, Department of Economics, MS 9074, Western Washington University, 516 \\ High St. Bellingham, WA, 98225, USA. Tel: 1-360-560-2180. E-mail: farrokh.kahnamoui@wwu.edu \\ Received: February 19, 2013 \\ Accepted: April 19, 2013 \\ Online Published: May 17, 2013 \\ doi:10.5539/ibr.v6n6p10 \\ URL: http://dx.doi.org/10.5539/ibr.v6n6p10
}

\begin{abstract}
This study investigates the impact of market size on how trade openness affects economic growth. A panel data of 60 developing countries is used and two measures of trade openness are interacted with four measures of market size. Although the interactive terms by themselves do not appear to be significant but the two measures of trade openness are positive and significant. Their positive impact on economic growth is generally robust in the presence of the measures of market size. Moreover, OLS estimation using both cross section and period fixed effects seems to be superior to using cross section fixed effects only.
\end{abstract}

Keywords: market size, trade openness, economic growth

\section{Introduction}

The main motivation behind this paper is derived from an article by Rodriguez and Rodrik (2001) in which they scrutinize a number of articles written on the impact of trade policy on economic growth with special focus on four major papers. The four papers are: Dollar (1992), Ben-David (1993) Sachs and Warner (1995), and Edwards (1998). Rodriguez and Rodrik (2001) conclude that the impact of trade policy on economic growth is far from clear and suggest further research into, what they term as, contingent relationships between the two. One such relationship, they suggest, could be between trade policy and country size. The aim of the present paper is to investigate this contingent relationship to find out if the size of the economy affects the impact of trade policy on economic growth. In this paper trade openness is used as a measure of trade policy. The research is focused on developing countries as there is a widespread interest among economists in the impact of trade policy in these countriesas evidenced by the vast body of literature written on this subject. See, for example, Sachs and Warner (1995) Edwards (1992 and 1998) Rodrik (1998), Stiglitz (2000), Dollar (2003) and Greenwald and Stiglitz (2006) among many others. Moreover, important international organizations, such as the IMF and the World Bank, routinely advocate trade liberalization as an essential factor for economic growth and poverty reduction in developing countries, see, for example, the IMF (1997) and Aksoy and Beghin (2004).

If trade openness has a positive impact on economic growth, as has been argued by Harrison (1996) Edwards (1998) Irwin and Tervio (2002), Baldwin (2003) and Bussiere, et al. (2011), among others, then one can suggest that this positive impact will probably be less for a large economy than a small one. One of the advantages of free trade is that it increases the incidents of the economies of scale because it increases the size of the market that had hitherto been available to the domestic producers. This advantage, however, may matter less for a country that already has a large market than a country that has a small one.

There are other ways that market size can influence the effectiveness of trade openness on growth. Hoekman, Kee and Olarreaga (2004) show that the impact of import tariffs (thus less trade openness), on firms' markup is negatively related to market size. Amable, Chatelain and Ralf (2004) argue that retained earnings have an impact on capital growth. As a result, to the extent that profits affect retained earnings, they will affect capital growth and finally economic growth. Levinsohn (1993), Harrison (1994), Roberts and Tybout (1996) and Hoekman, Keeand Olarreaga, (2004) are all studies that find support for the hypothesis that imports are a source of market discipline on domestic firm's behavior through increased competition. In case of a large economy, however, trade openness could have less of an expansive effect on domestic economy. The reason is that large economies 
are generally less dependent on foreign trade thus allowing imports into the domestic market will create less competition for domestic firms as compared to small economies. Trade openness may have less of a disciplinary impact on domestic firms in large economies than those in small economies.

Lee (1993) discusses the impact of tariffs (thus less trade openness) on growth in small versus large economies. In an open-economy model, which permits foreign inputs into the neoclassical production function, trade distortions caused by tariffs lower the long-run growth rate more significantly in a small, resource-scare economy than in a large resource-rich one. This may mean trade openness could help economic growth more in small economies than in large ones.

In summary, trade openness may affect economic growth less in large economies than in small economies because large economies depend less on trade and are less affected by foreign competition.

To measure the impact of trade openness on economic growth given the economy size, the same interpretation of a "large market" as the one used by Grabowski (1994) will be used in this paper. Here "large" is properly characterized by total GDP, GDP per capita, total population and a measure of income distribution. These four variables will be used in the model as measures of market size. A more detailed explanation as to why these four variables are important for the creation of a "large" market is given in a later section. Given the market size in each country, the impact of trade openness on economic growth of 60 developing countries over a 40 -year period will be examined.

\section{Methodology}

The model used in this paper is derived from a general neo-classical production function where output is a function of physical capital, human capital and population (as a proxy for labor force) in addition to the variables of interest in this paper namely trade openness and measures of market size. Initial GDP per capita is also used to address the issue of convergence. Neoclassical growth model asserts that per capita GDP growth is inversely related to initial GDP per capita Initial GDP per capita has been used by Barro (1991), Edwards (1992) and Mankiew (1992) among many others. Based on the important paper by Kormendi and Meguire (1985), many cross country regressions use explanatory variables in the model linearly and independently. See, for example, Bussiere, et al. (2011), Irwin and Tervio (2002) and Heady and Hodge (2009) among others. This practice is followed in this paper also.

The model is:

$$
G D P P C G R_{i t}=\beta_{l} \ln (I G D P P C)+\beta_{2} S C H_{i, t}+\beta_{3} T E L_{i t}+\beta_{4} T O_{i t}+\beta_{5} E M S_{i t}+\beta_{6} T O_{i t} * E M S_{i t}+\alpha_{t}+\eta_{i}+\varepsilon_{i t}
$$

GDPCPGR $_{i t}$ is per capita GDP growth rates averaged over the four sub periods 1970-1979, 1980-1989, 1990-1999 and 2000-2009, IGDPPC is the initial GDP per capita in the first year of each sub-period (1970, 1980,1990 and 2000) SCH is the percentage of population with secondary school education averaged over the four sub periods as a measure of human capital. TEL is the number of telephone main lines per 1000 people averaged over the four sub periods as a measure of physical capital. Telephone mainlines are an important part of a country's communications infrastructure which, in turn, plays an important role in economic growth see, for example, Chakraborty (2009) and Roberts and Deichmann (2011). Furthermore, telephone mainlines have been used in other studies see, for example, Yanikkaya (2003) and Butkiewicz and Yanikkaya (2005). TO is a measure of trade openness. $\alpha_{\mathrm{t}}$ and $\eta_{\mathrm{I}}$ are fixed effects and $\varepsilon_{\mathrm{it}}$ is a disturbance term. Two measures of trade openness will be used: one is the volume of trade as a percentage of GDP and the other is the Sachs-Warner trade liberalization index. This index is based on five criteria of trade restrictiveness; 1) Non-tariff barriers covering 40 percent or more of trade. 2) Average tariff rates of 40 percent or more. 3) A black market exchange rate that is depreciated by 20 percent or more relative to the official exchange rate. 4) A socialist economic system 5) A state monopoly on major exports. A country is considered "open" if it meets none of the five criteria in which case it receives a value of one. A country is considered "closed" if it meets any one criterion in which case it receives a value of zero. Despite criticism of the Sachs-Warner index (see, for example, Rodriguez \& Rodrik, 2001), it has been widely used in the empirical literature (Edwards, 1998, Lederman \& Fajnzylber, 1999, Clemens \& Willimason, 2002, among others). One important advantage of the Sachs-Warner (SW from hereon) index is that it considers more than one criterion for trade restrictiveness and as such can be considered a more comprehensive measure. One weakness of this index, however, is that it cannot measure the in-between countries. In other words a country is considered either open or closed, ignoring the degree to which it is so. EMS is the effective marker size that represents the factors that affect the market size. One can think of several such factors some of which were mentioned above. In this model, when "market size" is mentioned, what is really of interest is the size of the demand for goods that are produced domestically. A natural candidate is total GDP to capture the size of the economy. Aggregate demand is a function of aggregate income. Therefore the larger is the total GDP of an 
economy the larger will be the aggregate demand. One can also use total population to capture the market size. The number of people can affect the volume of demand for goods including the domestically produced ones. Of course, a large population alone may not necessarily create a large demand. Many poor people can create little demand. Therefore GDP per capita will be used to capture the effect of individual income on demand. Since initial GDP per capita is already used in the model as a control variable, it will be used in place of GDP per capita, which is the decadal average of GDP pc's over each sub-period, to avoid the problem of explanatory variable collinearity. Moreover, how income is distributed can affect aggregate demand. In a country where income is more evenly distributed there will be a broader market than in a country with less evenly distributed income. The GINI index as a measure of income distribution will be used to capture the effect of income distribution.

Therefore, several measures of effective market size will first be considered one ata time. They are:

1- Total population [TPOP]

2- Total GDP [TGDP]

3- GDP per capita [GDPPC] [proxied by initial GDP per capita to avoid collinearity]

4- The GINI Index [GINI]

Use of several measures allows consideration of several aspects of market demand. Moreover, they can also help distinguish among the theories given in the introduction For example, in traditional "economies of scale" explanations, GDP or population should be associated with how trade policy influences growth but the other variables should be less important. Since these measures of effective market size could also have direct influences on growth regardless of how they influence the effect of trade policy on growth, I also include each measure separately in the specification in addition to its inclusion in the interaction term. The trade openness enters the specification both by itself and as part of an interaction term. The coefficient $\beta_{3}$ captures the association between the trade openness and growth. However, the interaction term with EMS allows association between trade policies and growth to differ with "effective market size".

The cross-country regressions apply to a panel of 60 developing countries (for a list of these countries please see appendix A) over the period 1970-2009, divided into four sub-periods of 1970-1979, 1980-1989, 1990- 1999 and 2000-2009. Due to data availability on SW index a different set of countries (please see appendix B) and only three periods, 1970-1979,1980-1989 and 1990-1999 have been used when this index was used. Socialist and former socialist countries are excluded due to their different economic system. Major oil producing countries are also excluded since the bulk of their GDP is generated by extraction of natural resources (see Mankiew et al., 1992; Barro, 1997).

As a first check on the impact of trade openness on growth, scatter plots of growth against trade as percentage of GDP and SW index are run without using country specific differences. This will help show the general direction of growth in the presence of trade openness and also reveal the presence of any outlier. Figures 1 and 2 show the results that indicate a mildly positive relationship between these measures of trade openness on the one hand and growth rate of GDP per capita on the other.

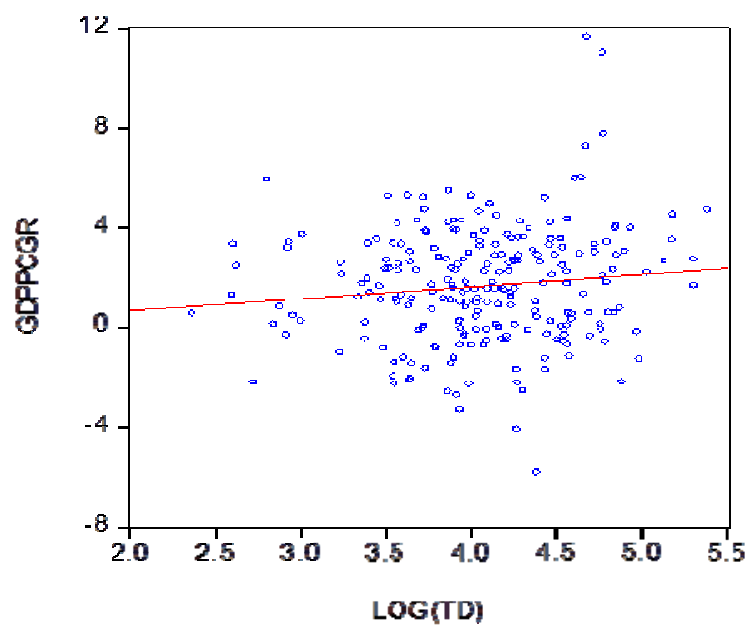

Figure 1. The scatter plot of GDP per capita growth rate and log of trade 


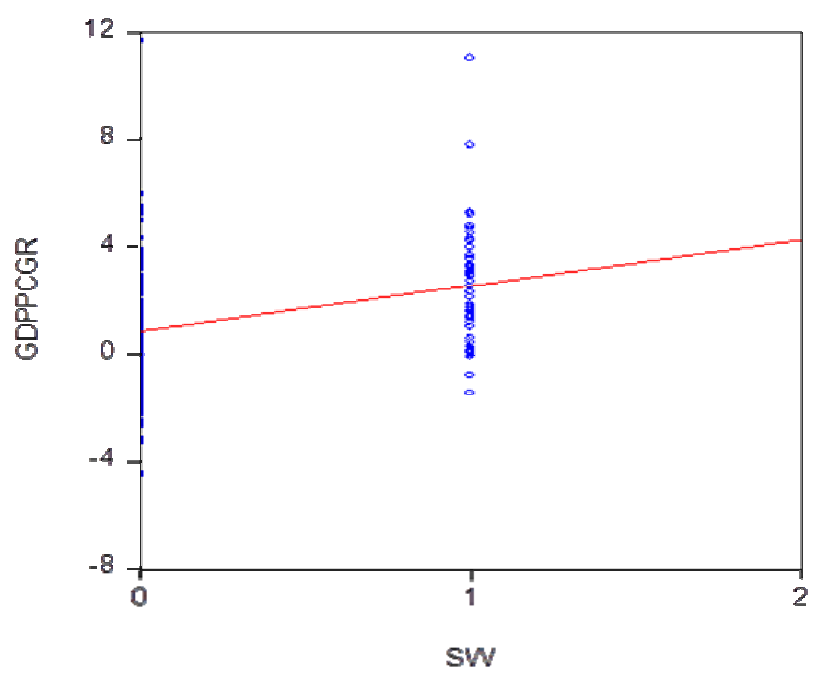

Figure 2. The scatter plot of GDP per capita growth rate and SW index

\section{Estimation Results}

The model has been estimated using OLS with both cross section fixed effects and period fixed effects as well as just cross section fixed effect and no period fixed effects. The results are reported in tables 1-4.

Table 1. Interactive effects of trade and measures of market size on per capita GDP growth rate

\begin{tabular}{|c|c|c|c|c|c|c|c|c|c|c|}
\hline Variables/Equations & 1 & 2 & 3 & 4 & 5 & 6 & 7 & 8 & 9 & 10 \\
\hline $\mathrm{C}$ & 27.17 & 72.16 & -70.56 & 23.63 & 104.55 & -79.80 & 20.08 & -7.07 & 84.38 & -74.58 \\
\hline $\mathrm{P}$ & $(0.00)$ & $(0.00)$ & $(0.00)$ & $(0.00)$ & $(0.00)$ & $(0.00)$ & $(0.06)$ & $(0.80)$ & $(0.00)$ & $(0.00)$ \\
\hline LOG(IGDPPC) & -4.68 & -4.89 & -8.19 & -3.98 & -5.02 & -8.15 & -3.60 & -4.15 & -4.74 & -8.42 \\
\hline $\mathrm{P}$ & $(0.00)$ & $(0.00)$ & $(0.00)$ & $(0.00)$ & $(0.00)$ & $(0.00)$ & $(0.02)$ & $(0.00)$ & $(0.00)$ & $(0.00)$ \\
\hline $\mathrm{LOG}(\mathrm{SCH})$ & -0.54 & -0.05 & -1.35 & -0.89 & 0.06 & -1.38 & -0.59 & -0.83 & -0.24 & -1.60 \\
\hline $\mathrm{P}$ & $(0.25)$ & $(0.92)$ & $(0.00)$ & $(0.24)$ & $(0.90)$ & $(0.00)$ & $(0.22)$ & $(0.27)$ & $(0.64)$ & $(0.00)$ \\
\hline LOG(TEL) & 1.34 & 1.23 & 1.02 & 0.95 & 1.14 & 1.02 & 1.28 & 1.02 & 1.28 & 1.06 \\
\hline $\mathrm{P}$ & $(0.00)$ & $(0.00)$ & $(0.00)$ & $(0.04)$ & $(0.00)$ & $(0.00)$ & $(0.00)$ & $(0.03)$ & $(0.00)$ & $(0.00)$ \\
\hline LOG(TD) & 1.95 & 1.86 & 1.48 & 1.87 & -4.15 & 3.52 & 3.52 & 9.82 & & \\
\hline $\mathrm{P}$ & $(0.00)$ & $(0.00)$ & $(0.00)$ & $(0.00)$ & $(0.35)$ & $(0.44)$ & $(0.11)$ & $(0.15)$ & & \\
\hline LOG(TPOP) & & -2.87 & & & -4.69 & & & & -3.10 & \\
\hline $\mathrm{P}$ & & $(0.02)$ & & & $(0.01)$ & & & & $(0.01)$ & \\
\hline LOG(TGDP) & & & 5.48 & & & 5.87 & & & & 6.03 \\
\hline $\mathrm{P}$ & & & $(0.00)$ & & & $(0.00)$ & & & & $(0.00)$ \\
\hline LOG(GINI) & & & & 0.24 & & & & 8.54 & & \\
\hline $\mathrm{P}$ & & & & $(0.85)$ & & & & $(0.24)$ & & \\
\hline LOG(TD)*LOG(TPOP) & & & & & 0.36 & & & & & \\
\hline $\mathrm{P}$ & & & & & $(0.17)$ & & & & & \\
\hline LOG(TD)*LOG(TGDP) & & & & & & -0.09 & & & & \\
\hline $\mathrm{P}$ & & & & & & $(0.65)$ & & & & \\
\hline LOG(TD)*LOG(IGDPPC) & & & & & & & -0.24 & & & \\
\hline $\mathrm{P}$ & & & & & & & $(0.46)$ & & & \\
\hline LOG(TD)*LOG(GINI) & & & & & & & & -2.10 & & \\
\hline $\mathrm{P}$ & & & & & & & & $(0.25)$ & & \\
\hline $\mathrm{R}^{2}$ & 0.74 & 0.75 & 0.79 & 0.76 & 0.75 & 0.79 & 0.74 & 0.77 & 0.72 & 0.77 \\
\hline No. of Countries & 59 & 59 & 59 & 58 & 59 & 59 & 59 & 58 & 59 & 59 \\
\hline No of Observations & 216 & 216 & 216 & 178 & 216 & 216 & 216 & 216 & 217 & 217 \\
\hline
\end{tabular}

Table 1, shows the results where both cross section and period fixed effects have been used with trade as a measure of openness. The coefficients for trade are positive and significant at $1 \%$ in equations 1 through 4 where all the measures of market size are also present but no interactive terms are used. For every one percentage 
increase in trade, GDP per capita growth rate will increase by between 1.48 and 1.95 percentage points. In equations 2 and 5, total population is negative and significant at $5 \%$ and $1 \%$ respectively. As mentioned above, the measures of market size used in this paper can have direct impact on economic growth independent of their indirect impact via trade openness. The negative coefficient for total population should be viewed in this light. To test this conjecture, growth was regressed on total population without the presence of trade but using the same control variables, the coefficient turns out negative again and significant at $1 \%$. The results are shown in equation 9. The negative impact of total population on economic growth has been suggested in the literature, for example, Wong and Furuoka, (2005) and Headey and Hodge (2009) among others. The latter paper analyzes 29 prominent studies on this subject and finds strong evidence of adverse impact of population growth on economic growth. In equations 3 and 6 , total GDP's coefficient is positive and significant at $1 \%$. Once again this may be due to direct impact of total GDP on economic growth independent of any indirect impact via trade openness. Similar to the case of total population, GDP per capita growth rate was regressed on total GDP without the presence of trade openness. Once again the coefficient for total GDP is positive and significant at $1 \%$. The results are shown under equation 10. Exactly why such a positive relationship exists should be the subject of further research. In equations 5 through 8 where trade is interacted with the four measures of market size, the coefficients for the interactive terms are not significant.

Table 2. Interactive effects of SW index and measures of market size on per capita GDP growth rate

\begin{tabular}{|c|c|c|c|c|c|c|c|c|}
\hline Variables/Equation & 1 & 2 & 3 & 4 & 5 & 6 & 7 & 8 \\
\hline $\mathrm{C}$ & 28.85 & 29.45 & 27.87 & 33.98 & 28.57 & 27.71 & 28.78 & 29.15 \\
\hline $\mathrm{P}$ & $(0.00)$ & $(0.00)$ & $(0.00)$ & $(0.00)$ & $(0.00)$ & $(0.00)$ & $(0.00)$ & $(0.00)$ \\
\hline LOG(IGDPPC) & -4.22 & -4.38 & -3.94 & -4.31 & -4.30 & -4.03 & -4.23 & -4.04 \\
\hline $\mathrm{P}$ & $(0.00)$ & $(0.00)$ & $(0.00)$ & $(0.00)$ & $(0.00)$ & $(0.00)$ & $(0.00)$ & $(0.00)$ \\
\hline $\mathrm{SCH}$ & 0.01 & 0.002 & -0.02 & 0.00 & 0.04 & 0.01 & 0.02 & -0.01 \\
\hline $\mathrm{P}$ & $(0.22)$ & $(0.91)$ & $(0.54)$ & $(0.87)$ & $(0.21)$ & $(0.79)$ & $(0.58)$ & $(0.75)$ \\
\hline TEL & 0.06 & 0.09 & 0.06 & 0.09 & 0.06 & 0.07 & 0.07 & 0.07 \\
\hline $\mathrm{P}$ & $(0.28)$ & $(0.14)$ & $(0.28)$ & $(0.14)$ & $(0.32)$ & $(0.21)$ & $(0.29)$ & $(0.25)$ \\
\hline SW & 0.91 & 1.17 & 0.96 & 0.69 & 1.14 & 1.00 & 1.66 & 3.69 \\
\hline $\mathrm{P}$ & $(0.07)$ & $(0.02)$ & $(0.05)$ & $(0.29)$ & $(0.03)$ & $(0.05)$ & $(0.53)$ & (0.13) \\
\hline ТPOP & & 0.00 & & & & & & \\
\hline $\mathrm{P}$ & & $(0.00)$ & & & & & & \\
\hline TGDP & & & 0.00 & & & & & \\
\hline $\mathrm{P}$ & & & $(0.38)$ & & & & & \\
\hline GINI & & & & -0.07 & & & & \\
\hline$P$ & & & & $(0.01)$ & & & & \\
\hline SW*TPOP & & & & & 0.00 & & & \\
\hline $\mathrm{P}$ & & & & & $(0.09)$ & & & \\
\hline SW*TGDP & & & & & & 0.00 & & \\
\hline $\mathrm{P}$ & & & & & & $(0.23)$ & & \\
\hline SW*LOG(IGDPPC) & & & & & & & -0.11 & \\
\hline $\mathrm{P}$ & & & & & & & $(0.78)$ & \\
\hline $\mathrm{SW}^{*} \mathrm{GINI}$ & & & & & & & & -0.06 \\
\hline $\mathrm{P}$ & & & & & & & & $(0.34)$ \\
\hline $\mathrm{R}^{2}$ & 0.75 & 0.77 & 0.77 & 0.78 & 0.82 & 0.76 & 0.75 & 0.81 \\
\hline No. of countries & 57 & 57 & 56 & 56 & 55 & 57 & 57 & 55 \\
\hline No. of observations & 160 & 160 & 157 & 157 & 122 & 160 & 160 & 122 \\
\hline
\end{tabular}

Table 2, shows the results where both cross section and period fixed effects have been used with SW index as a measure of openness. The coefficients for SW index are positive and significant at $5 \%$ and $10 \%$ in equations 1 through 3, 5 and 6 . In equation 4 , the GINI coefficient is negative and significant at $1 \%$ which is in line with the general notion that widening income gap can adversely impact economic growth, see, for example Alesina and Rodrik (1994) and Deninger and Squire (1998) among others. The interactive terms, however, are not significant. In equation 2, total population is significant at $1 \%$ and in equation 5 the interactive term between $\mathrm{SW}$ and total population is significant at $10 \%$ but the magnitudes of the coefficients are negligible. 
Table 3. Interactive effects of trade and measures of market size on per capita GDP growth rate

\begin{tabular}{|c|c|c|c|c|c|c|c|c|}
\hline Variables\Equations & 1 & 2 & 3 & 4 & 5 & 6 & 7 & 8 \\
\hline $\mathrm{C}$ & 33.53 & 82.23 & -35.45 & 28.00 & 116.73 & -32.25 & -11.96 & 29.01 \\
\hline $\mathrm{P}$ & $(0.00)$ & $(0.00)$ & $(0.00)$ & $(0.00)$ & $(0.00)$ & $(0.28)$ & $(0.69)$ & $(0.01)$ \\
\hline LOG(IGDPPC) & -5.05 & -5.64 & -7.02 & -4.69 & -5.83 & -7.04 & -4.85 & -4.37 \\
\hline $\mathrm{P}$ & $(0.00)$ & $(0.00)$ & $(0.00)$ & $(0.00)$ & $(0.00)$ & $(0.00)$ & $(0.00)$ & $(0.01)$ \\
\hline LOG(SCH) & -1.49 & -0.45 & -2.45 & -1.40 & -0.30 & -2.44 & -1.36 & -1.50 \\
\hline $\mathrm{P}$ & $(0.00)$ & $(0.41)$ & $(0.00)$ & $(0.06)$ & $(0.59)$ & $(0.00)$ & $(0.07)$ & $(0.00)$ \\
\hline LOG((TEL) & 1.38 & 1.90 & 0.41 & 1.28 & 1.88 & 0.41 & 1.28 & 1.38 \\
\hline $\mathrm{P}$ & $(0.00)$ & $(0.00)$ & $(0.24)$ & $(0.00)$ & $(0.00)$ & $(0.24)$ & $(0.00)$ & $(0.00)$ \\
\hline LOG(TD) & 1.81 & 1.95 & 1.23 & 2.04 & -5.32 & 0.53 & 12.43 & 2.86 \\
\hline $\mathrm{P}$ & $(0.00)$ & $(0.00)$ & $(0.02)$ & $(0.00)$ & $(0.26)$ & $(0.92)$ & $(0.10)$ & $(0.24)$ \\
\hline LOG(TPOP) & & -3.11 & & & -5.06 & & & \\
\hline$P$ & & $(0.00)$ & & & $(0.00)$ & & & \\
\hline LOG(TGDP) & & & 3.86 & & & 3.72 & & \\
\hline$P$ & & & $(0.00)$ & & & $(0.00)$ & & \\
\hline LOG(GINI) & & & & 0.64 & & & 11.40 & \\
\hline $\mathrm{P}$ & & & & $(0.64)$ & & & $(15.00)$ & \\
\hline LOG(TD)*LOG(TPOP) & & & & & 0.44 & & & \\
\hline $\mathrm{P}$ & & & & & $(0.12)$ & & & \\
\hline LOG(TD)*LOG(TGDP) & & & & & & 0.03 & & \\
\hline $\mathrm{P}$ & & & & & & $(0.90)$ & & \\
\hline LOG(TD)*LOG(GINI) & & & & & & & -2.73 & \\
\hline$P$ & & & & & & & $(0.16)$ & \\
\hline LOG(TD)*LOG(IGDPPC) & & & & & & & & -0.16 \\
\hline$P$ & & & & & & & & $(0.66)$ \\
\hline $\mathrm{R}^{2}$ & 0.66 & 0.69 & 0.70 & 0.71 & 0.69 & 0.70 & 0.72 & 0.66 \\
\hline No. of Countries & 59 & 59 & 59 & 58 & 59 & 59 & 58 & 59 \\
\hline No. of Observations & 216 & 216 & 216 & 178 & 216 & 216 & 178 & 216 \\
\hline
\end{tabular}

Table 4. Interactive effects of SW index and measures of market size on per capita GDP growth rate

\begin{tabular}{|c|c|c|c|c|c|c|c|c|}
\hline Variables \Equations & 1 & 2 & 3 & 4 & 5 & 6 & 7 & 8 \\
\hline $\mathrm{C}$ & 32.10 & 32.84 & 30.91 & 36.88 & 33.02 & 32.82 & 36.84 & 32.1 \\
\hline $\mathrm{P}$ & $(0.00)$ & $(0.00)$ & $(0.00)$ & $(0.00)$ & $(0.00)$ & $(0.00)$ & $(0.00)$ & $(0.00)$ \\
\hline LOG(IGDPPC) & -4.50 & -4.63 & -4.23 & -4.58 & -4.69 & -4.58 & -4.59 & -4.49 \\
\hline $\mathrm{P}$ & $(0.00)$ & $(0.00)$ & $(0.00)$ & $(0.00)$ & $(0.00)$ & $(0.00)$ & $(0.00)$ & $(0.00)$ \\
\hline $\mathrm{SCH}$ & -0.03 & -0.04 & -0.05 & -0.03 & -0.03 & -0.05 & -0.03 & -0.03 \\
\hline $\mathrm{P}$ & $(0.25)$ & $(0.08)$ & $(0.04)$ & $(0.28)$ & $(0.18)$ & $(0.07)$ & $(0.29)$ & $(0.24)$ \\
\hline TEL & 0.08 & 0.09 & 0.09 & 0.11 & 0.09 & 0.09 & 0.11 & 0.07 \\
\hline $\mathrm{P}$ & $(0.17)$ & $(0.11)$ & $(0.14)$ & $(0.06)$ & $(0.12)$ & $(0.11)$ & $(0.07)$ & $(0.30)$ \\
\hline SW & 1.13 & 1.21 & 1.32 & 0.78 & 1.33 & 1.43 & 1.07 & 0.25 \\
\hline $\mathrm{P}$ & $(0.01)$ & $(0.00)$ & $(0.00)$ & $(0.15)$ & $(0.00)$ & $(0.00)$ & $(0.67)$ & $(0.92)$ \\
\hline ТPOP & & 0.00 & & & 0.00 & & & \\
\hline $\mathrm{P}$ & & $(0.00)$ & & & $(0.01)$ & & & \\
\hline TGDP & & & 0.00 & & & 0.00 & & \\
\hline $\mathrm{P}$ & & & $(0.23)$ & & & $(0.07)$ & & \\
\hline GINI & & & & -0.07 & & & -0.07 & \\
\hline $\mathrm{P}$ & & & & $(0.01)$ & & & $(0.02)$ & \\
\hline SW*TPOP & & & & & 0.00 & & & \\
\hline $\mathrm{P}$ & & & & & $(0.37)$ & & & \\
\hline SW*TGDP & & & & & & 0.00 & & \\
\hline $\mathrm{P}$ & & & & & & $(0.13)$ & & \\
\hline $\mathrm{SW}^{*} \mathrm{GINI}$ & & & & & & & -0.01 & \\
\hline $\mathrm{P}$ & & & & & & & $(0.91)$ & \\
\hline SW*LOG(IGDPPC) & & & & & & & & 0.13 \\
\hline $\mathrm{P}$ & & & & & & & & $(0.72)$ \\
\hline $\mathrm{R}^{2}$ & 0.72 & 0.74 & 0.74 & 0.80 & 0.75 & 0.75 & 0.80 & 0.72 \\
\hline No. of countries & 57 & 57 & 56 & 55 & 57 & 56 & 55 & 57 \\
\hline No. of observations & 160 & 160 & 157 & 122 & 160 & 157 & 122 & 160 \\
\hline
\end{tabular}


Table 3, has the results where only cross section fixed effects but no period fixed effects have been used with trade as a measure of openness. Similar to table 1 , trade has positive coefficients which are significant at $1 \%$ in equations 1 through 4 . For every 1 percentage increase in trade, GDP per capita growth rate will increase between 1.23 and 2.04 percentage points. As in table 1, total population is negative and significant at $1 \%$ in equations 2 and 5 while total GDP is positive and significant at $1 \%$ in equations 3 and 6 respectively. The interactive terms are not significant.

Table 4, has the results where only cross section fixed effects but no period fixed effects have been used with the SW index as a measure of openness. This index has positive and significant coefficients at $1 \%$ in equations 1 through 3,5 and 6. The coefficient for GINI index is negative and significant at $1 \%$, once again in line with the general notion about the adverse impact of income gap on economic growth. The remainder of the market size measures are either not significant or have negligible magnitudes.

\section{Conclusion}

The two measures of trade openness, trade as a percentage of GDP and SW index, used in this study are shown to have positive and significant impact on economic growth. In most cases this impact is robust in the presence of market size measures namely, total population, total GDP, GINI index and GDP per capita. In the case of GINI index, the coefficient for this index has the expected (negative) sign and is significant. This finding weakens the proposition that market size makes any difference in how trade affects economic growth but supports the positive impact of trade on economic growth as has been argued in trade and growth literature cited above and proposed by the IMF and the World Bank. The results of the current study show that trade leads to more than proportionate growth in GDP per capita. Total population negatively affects economic growth when not interacted with trade openness measures or when estimated without the presence of these measures. This relationship is supported in the literature as mentioned above. Where either trade or SW index have been interacted with the measures of market size, the results are mostly not significant or are negligible. There seems to be no evidence for the so called "contingent relationship" between trade openness and economic growth as far as market size is concerned. One possible explanation, in the case of two of the market size measures, namely total population and initial GDP per capita, is that trade openness has a positive impact on economic growth but when interacted with total population or initial GDP per capita the negative impact of these measures reduces the positive impact of trade thus neutralizing the interactive impact on growth. The same can be said about the negative impact of the GINI index when it is interacted with the SW trade liberalization index. These results do not change in any significant way when estimation is done with both cross section and period fixed effects or with cross section fixed effects only. However, using both cross section and period fixed effects seems to be somewhat superior to using cross section fixed effects only. The average coefficients of determination when trade is used is 0.76 under both cross section and period fixed effects as compared to 0.69 under cross section fixed effects only. When SW index is used, the average coefficient of determination is 0.78 under both cross section and period fixed effects as compared to 0.75 under cross section fixed effects only.

\section{References}

Aksoy, M. A., \& Beghin, J. C. (2004). Global Agricultural Trade and Developing Countries. World Bank Publications.

Alesina, A., \& Rodrik, D. (1994). Distributive politics and economic growth. Quarterly Journal of Economics, 109(2), 465-90. http://dx.doi.org/10.2307/2118470

Amable, B., Chatelain, J. B., \& Ralf, K. (2004). Credit Rationing, Profit Accumulation and Economic Growth. Economics Letters, 85(3), 301-07. http://dx.doi.org/10.1016/j.econlet.2004.03.034

Baldwin, R. (2003). Openness and Growth, What is the Empirical Relationship? NBER working paper, no. 9578.

Barro, R. (1991). Economic growth in a cross section of countries. Quarterly Journal of Economics, 106. http://dx.doi.org/10.2307/2937943

Barro, R. J. (1997). Determinants of economic growth: A cross-country empirical study. Lionel Robbins Lectures (p xii, 145). Cambridge and London: MIT Press.

Ben-David, D. (1993). Equalizing exchange: Trade liberalization and income convergence. Quarterly Journal of Economics, 108(3). http://dx.doi.org/10.2307/2118404

Bussière, M., Pérez-Barreiro, E., Straub, R., \& Taglioni, D. (2011). Protectionist Responses to the Crisis: Global Trends and Implications. World Economy, 34(5), 826-852. http://dx.doi.org/10.1111/j.1467-9701.2011.01355.x 
Butkiewicz, J., \& Yankkiaya, H. (2005). The Effects of IMF and World Bank Lending on Long-Run Economic Growth: An Empirical Analysis. World Development, 33(3), 371-391. http://dx.doi.org/10.1016/j.worlddev.2004.09.006

Chakraborty, C., \& Nandi, B. (2009). Telecommunications Adoption and Economic Growth in Developing Countries: Do Levels of Development Matter? Journal of the Academy of Business \& Economics, 9(2), 51-61.

Clemens, M. A., \& Williamson, J. G. (2002). Why Did the Tariff-Growth Correlation Reverse After 1950? NBER Working Papers, 9181.

Deininger, K., \& Squire, L. (1998). New ways of looking at old issues: inequality and growth. Journal of Development Economics, 57, 259-87. http://dx.doi.org/10.1016/S0304-3878(98)00099-6

Dollar, D. (1992). Outward-oriented developing economies really do grow more rapidly: Evidence from 95 LDCs, 1976-85. Economic Development and Cultural Change, 523-544. http://dx.doi.org/10.1086/451959

Dollar, D. (2003). Globalization and Poor Nations: Opportunities and Risks. Phi Kappa Phi Forum, 83(4), 26-29.

Edwards, S. (1992). Trade orientation, distortions, and growth in developing countries. Journal of Development Economics, 39, 31-57. http://dx.doi.org/10.1016/0304-3878(92)90056-F

Edwards, S. (1998). Openness, productivity and growth: what do we really know? Economic Journal, 108, 383-398. http://dx.doi.org/10.1111/1468-0297.00293

Grabowski, R. (1994). The Successful Developmental State: Where does it come from? World Development, 22(3), 413-422. http://dx.doi.org/10.1016/0305-750X(94)90131-7

Greenwald, B., \& Stiglitz, J. (2006). Helping Infant Economies Grow: Foundations of Trade Policies for Developing Countries. American Economic Review, 96(2), 141-146. http://dx.doi.org/10.1257/000282806777212206

Harrison, A. (1994). Productivity, imperfect competition and trade reform: theory and evidence. Journal of International Economics, 36, 53-73. http://dx.doi.org/10.1016/0022-1996(94)90057-4

Harrison, A. (1996). Openness and growth: a time series, cross-country analysis for developing countries. Journal of Development Economics, 48, 419-447. http://dx.doi.org/10.1016/0304-3878(95)00042-9

Headey, D. D., \& Hodge, A. (2009). The Effect of Population Growth on Economic Growth: A Meta-Regression Analysis of the Macroeconomic Literature. Population \& Development Review, 35(2), 221-248. http://dx.doi.org/10.1111/j.1728-4457.2009.00274.x

Hoekman, B., Kee, L., \& Olarreaga, M. (2004). Tariffs, Entry Regulation and Markups: Country Size Matters. Contributions to Macroeconomics, 4(1), 1-22. http://dx.doi.org/10.2202/1534-6005.1260

Irwin, D., \& Trevio, M. (2002). Does Trade Raise Income? Evidence from the Twentieth Century. Journal of International Economics, 58(1), 1-18. http://dx.doi.org/10.1016/S0022-1996(01)00164-7

Kormendi, R., \& Meguire, P. (1985). Macroeconomic Determinants of Growth. Journal of Monetary Economics, 16(2), 141-163. http://dx.doi.org/10.1016/0304-3932(85)90027-3

Lederman, D., \& Fajnzylber, P. (1999). Economic Reforms and Total Factor Productivity Growth in Latin America and the Caribbean (1950-95): An Empirical Note. The World Bank Policy Research Working Paper Series, 2114.

Lee, J. W. (1993). International trade, Distortions and Long Run Economic Growth. International Monetary Fund Staff Papers, 299. http://dx.doi.org/10.2307/3867316

Levinsohn, J. (1993). Testing the imports-as-market-discipline hypothesis. Journal of International Economics, 35, 1-22. http://dx.doi.org/10.1016/0022-1996(93)90002-F

Mankiw, N. G., Romer, D., \& Weil, D. N. (1992). A Contribution to the Empirics of Economic Growth. The Quarterly Journal of Economics, 107(2), 407-37. http://dx.doi.org/10.2307/2118477

Roberts, M., \& Deichman, U. (2011). International Growth Spillovers, Geography and Infrastructure. The World Economy, 34(9), 507-1533. http://dx.doi.org/10.1111/j.1467-9701.2011.01392.x

Roberts, M., \& Tybout, J. (1996). Industrial Evolution in Developing Countries. Oxford University Press.

Rodriguez, F., \& Rodrik, D. (2001). Trade policy and economic growth: a skeptic's guide to the cross-national 
evidence. In Bernanke, B. S., \& Rogoff, K. (Eds.), NBER, Macroeconomics Annual. Cambridge: MIT Press.

Rodrik, D. (1998). The Limits of Trade Policy Reform in Developing Countries. Developing and newly industrializing countries, 1, 20-38.

Sachs, J. D., \& Warner, A. (1995). Economic Reform and the Process of Global Integration. Brookings Papers on Economic Activity, 1, 1-118. http://dx.doi.org/10.2307/2534573

Stiglitz, J. (2000). Two Principles for the Next Round or, How to Bring Developing Countries in from the Cold. World Economy, 23(4), 437. http://dx.doi.org/10.1111/1467-9701.00283

The IMF. (1997). World Economic Outlook, Washington. p. 84.

Wong, H. T., \& Furuoka, F. (2005). The Relationship between Population and Economic Growth in Asian Economies. ASEAN Economic Bulletin, 22(3), 314-330. http://dx.doi.org/10.1355/AE22-3E

Yanikkaya, H. (2003). Trade Openness and Economic Growth, A Cross-Country Empirical Investigation. Journal of Development Economics, 72, 57-89. http://dx.doi.org/10.1016/S0304-3878(03)00068-3

\section{Appendix A}

\begin{tabular}{|c|c|}
\hline Argentina & Kenya \\
\hline Bangladesh & Lesotho \\
\hline Barbados & Madagascar \\
\hline Bolivia & Malawi \\
\hline Botswana & Malaysia \\
\hline Brazil & Mali \\
\hline Burkina Faso & Mauritania \\
\hline Cameroon & Mauritius \\
\hline Chile & Mexico \\
\hline Colombia & Morocco \\
\hline Costa Rica & Nepal \\
\hline Cote d'Ivoire & Niger \\
\hline Dom. Rep. & Nigeria \\
\hline Ecuador & Pakistan \\
\hline Egypt & Panama \\
\hline El Salvador & Paraguay \\
\hline Fiji & Peru \\
\hline Gabon & Philippines \\
\hline Gambia & Senegal \\
\hline Ghana & South Africa \\
\hline Guatemala & Sri Lanka \\
\hline Guinea & Tanzania \\
\hline Guinea Bissau & Thailand \\
\hline Guyana & Trinidad and Tobago \\
\hline Haiti & Tunisia \\
\hline Honduras & Turkey \\
\hline India & Uganda \\
\hline Indonesia & Uruguay \\
\hline Jamaica & Zambia \\
\hline Jordan & Zimbabwe \\
\hline
\end{tabular}




\section{Appendix B}

Argentina

Bangladesh

Barbados

Benin

Bolivia

Botswana

Brazil

Burkina Faso

Burundi

Cameroon

Central African Rep.

Chad

Chile

Colombia

Congo

Costa Rica

Dominican Republic

Ecuador

Egypt, Arab Rep.

El Salvador

Ethiopia

Gambia, The

Ghana

Guatemala

Guinea

Guinea-Bissau

Guyana

Haiti

Honduras

India

Indonesia
Jamaica

Jordan

Kenya

Madagascar

Malawi

Malaysia

Mali

Mauritania

Mauritius

Mexico

Morocco

Nepal

Niger

Pakistan

Papua N Guinea

Paraguay

Peru

Philippines

Sierra Leone

South Africa

Sri Lanka

Syria

Thailand

Togo

Trinidad and Tobago

Tunisia

Turkey

Uganda

Uruguay

Zambia

Zimbabwe 